\title{
Obituaries
}

Obituaries should be submitted by email to Laura Pacey at I.pacey@nature.com.

All submitted obituaries should be 350 words maximum in length (apart from obituaries for past presidents of the BDA where the length should be $700-800$ words).

Content of the obituary is down to the individual author, and the approval of the family should be given for the obituary prior

to submission to the $B D J$.

\section{JEAN SMITH MBE}

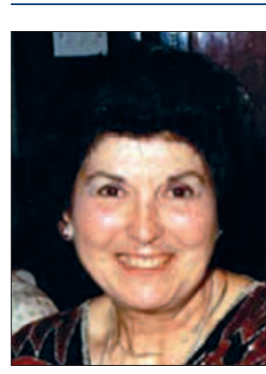

10 June $1923-20$

April 2012.

Following the

Second World

War there was great difficulty in recruiting suitable 'dental chairside attendants', with no

formal training available, and pay and recognition poor. It was in this environment that the young Jean Smith found herself, and where she devoted herself tirelessly for almost 40 years.

In 1945, Jean passed the new dental nurses qualification and joined the Dental Nurses and Assistants Society. In 1948, Jean replied to an advertisement for a secretary to the society, which stated that, unless someone came forward at once, the society would cease to function. Luckily Jean was appointed and this was not to be the only time she saved the day!

Jean met with representatives from any dental organisation who could influence and promote education and training for dental nurses, succeeding in increasing the number of courses, candidates and examiners. In 1954, the BDA and the BDNA agreed to form a joint committee. Recommendations on pay and conditions for dental nurses in general dental practice were issued and a National Voluntary Register was established. Jean administered the register and became the first registrar. By this time Jean had taken on the additional role as secretary to the National Examining Board. Both the association and examining board made considerable progress under her intelligent leadership and her services to dentistry were recognised in 1975 when Jean was awarded an MBE.
Jean was determined to get proper recognition for dental nurses and in 1980, approaches were made to the GDC to set up a group of stakeholders to standardise their training and education. A report in 1984 outlined, for the first time, the role and training objectives for dental nurses.

Jean retired from the association in 1985, but continued to work for the Examining Board, which by now had become a separate organisation. Her signature will be recognised by thousands of dental nurses who received her letter telling them their examination results.

Jean retired from her official duties with the board in December 1991, after over 40 years of dedicated service. Her impact on the dental nursing profession is without equal.

Jean leaves a daughter Jennifer, grandchildren Diane and Joel and great granddaughters Natalie, Hannah, Isobel and Alexandra.

\section{Diana Wincott MBE}

\section{GEOFFREY PEARSON}

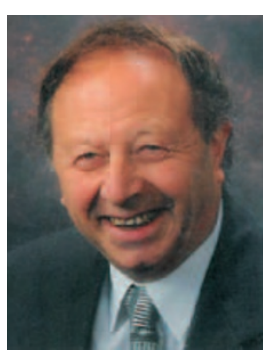

Geoffrey Pearson of Cottingham, Humberside, sadly passed away on 29 May, 2012. Geoff was a stalwart member of the BDA, having joined shortly after qualifying LDS in Birmingham 1958, following his school education at Hull Grammar School. Sadly, at 14 Geoff lost his mother. To help fund his way at dental school he worked as a hospital porter. On qualifying, he worked as an assistant GDP in Hull before transferring his talents to the community dental services and developing a long lasting relationship between the GDS and CDS in Humberside. He obtained an MDSc from Leeds University in 1979, and DDPH, RCS in 1980.

Early on in his career he became an active member of the Central Committee for Community Dental Services (CCCDS) and was elected to the BDA representative board in 1970, a position he held for over 25 years, during which time he was president of the Yorkshire branch (1979-80). Geoffrey also became a trustee of the benevolent fund for over 30 years until 2005, dispensing wise advice in his quiet unassuming manner. His views as District Dental Officer were sought, and were diplomatically and sometimes forcefully aired at health authority and Yorkshire regional dental committees.

Geoff was assiduous in attending Yorkshire branch council and Hull section meetings even after his retirement in 1999 and the branch had the pleasure of congratulating him on his BDA life membership. He was also a long time member of the Lindsay Society and wrote a comprehensive history of the BDA's Yorkshire branch.

Geoffrey had many other interests, being an active member of the local Conservative Association, a passionate season ticket holder for Hull City Football Club, a self-taught guitarist and a pianist of some ability. He was also proficient in German, and a story is told of him telling German visitors in their own language about Yorkshire coastal birdlife, as a member of the RSPB.

His many friends and colleagues extend their commiserations to his wife Brenda, daughter Fiona and son-in-law Neil over their sad loss.

Stuart Robson 